\title{
A Foucauldian Theory of American Islamophobia
}

\author{
SHYAM K. SRIRAM ${ }^{1}$
}

\begin{abstract}
With the emergence of ISIS andAmerican public furor over allowing Syrian refugees safe haven, Muslim Americans find themselves once again in the cross-hairs of a nation obsessed with searching for answers and someone to blame. I argue that the premise behind American anti-Muslim sentiment is rooted in two of Michel Foucault's concepts - "biopower" and "pastoral power." This article is divided in two halves. In the first, I argue that American nationalism is articulated in a unique way, particularly through "pastoral power." In conjunction with an "imagined" American nationhood (Anderson 1983), it has created a state that is often viewed as secular, but is quite Christian ideologically and structurally. Drawing on Göle (1996), I surmise that the Western "culture of confession," an extension of pastoral power, is incompatible with Islam - or at least is viewed as such. In the second half, I present my main argument towards a new understanding of Foucault's (1990) biopower in the context of the sovereign and its ability to designate who is "sacred," a la Agamben (1998). I suggest that a new evaluation of Agamben (1998) should be undertaken to account for the renewed racialization of and discrimination towards American Muslims.
\end{abstract}

Keywords: biopower, Foucauldian Theory, Islamophobia, Islam in the United States

In the weeks immediately following the events of September $11^{\text {th }}, 2001$, the United States found a way to unite itself through the widespread use and display of American flags, and in common rhetoric and statements such as "America fights back" and the "War on Terror." Yet, this construction of a contextually-American form of nationalism, had, at its core, a set of membership requirements (Anderson 1983), which were suddenly not open to Muslims or those of Arab and South Asian descent. For Americans of these ethnic and religious backgrounds, this membership exclusion led to "a reign of domestic terror that targeted Muslim Americans and those who appeared Muslim [which] inaugurated a twenty-first century racial order" (Rana 2013: 325). Muslims, formerly identified by a religious affiliation, became racialized, and anti-Muslim racism became the norm.

With the emergence of ISIS and the radical Islam-related terrorist incidents around the world, as well as recent discussion about allowing Syrian refugees safe haven in the United States, Muslim Americans find themselves once again in the cross-hairs of a nation obsessed with searching for answers and someone to blame. Yet the anti-Muslim rhetoric that has gripped the United States over the last few months seems altogether different from that of 2001. It has sprouted from an environment that, over the last few years, has become increasingly toxic to Islam in the United States and views Muslims unable to assimilate into American culture.

${ }^{1}$ Shyam K. Sriram, Ph.D. student at the Department of Political Science, University of California, Santa Barbara, CA 93106, USA, email: shyam@umail.ucsb.edu.

https://doi.org/10.24035/ijit.10.2016.005 
I argue that the premise behind American anti-Muslim sentiment is rooted in two of Michel Foucault's concepts - "biopower" as outlined in The History of Sexuality, Vol. 1 (1978) (and its expansion by Agamben (1998) with his theory of "homo sacer"), and "pastoral power," as outlined in "The Subject and Power" (Foucault 1982). This paper is divided in two halves. In the first, I argue that American nationalism is articulated in a unique way, particularly through Foucault's (1982) concept of "pastoral power." In conjunction with an "imagined" American nationhood (Anderson 1983), it has created a state that is often viewed as secular, but is quite Christian ideologically and structurally. Drawing on Göle (1996), I surmise that the Western "culture of confession," an extension of pastoral power, is incompatible with Islam - or at least is viewed as such. I also build on Said (1978) and Smith (1978) to argue that the current racism and intolerance towards Muslims may be viewed as part of a larger scheme of "othering."

In the second half, I use the preceding section to lay the groundwork for my main argument towards a new understanding of Foucault's (1990) biopower in the context of the sovereign and its ability to designate who is "sacred," a la Agamben (1998). I suggest that a new evaluation of Agamben (1998) should be undertaken to account for the renewed racialization of and discrimination towards American Muslims and that Foucault's (1978) "process of subjectivation" has resulted in the difficult position of Muslims, who are allowed to exist in the "juridical order," but are at the whim of the sovereign to their exclusion. This has created a situation, for Asad (2003), where Muslims are simultaneously chastised for not being louder in the public sphere, but are also unable to speak because their voices are muted, and a political arena bombarded with debates of "good" versus "bad" religion, and Muslims inevitably positioned in the latter (Sullivan 2014).

\section{Towards a New Understanding of American Political Culture}

The political culture of the United States has long been a topic of interest for citizens, as well as visitors, who have sought to theorize why America has a particular culture, and how that culture engenders certain behaviors and institutions. In the current anti-Muslim climate in the United States, it is helpful to theorize how the United States' identity came into being in order to set the stage for a discussion of where Islam fits into that identity. At the heart of any debate about inclusion and belonging, must be a discussion of the formation of "the Other." Religious historian J.Z. Smith (1978) has written that "the process of comparison is a fundamental characteristic of human intelligence" (p. 240); taken another way, to compare oneself or one's community with another is about as basic a function of human interaction as any. However, once the actual comparison is finished, the harder work is still left to do - "a place must be found for the other within or without one's cosmos" (p. 241). In order to aid our understanding, Smith (1978) outlines four scenarios of comparison that work for just about every situation of human interaction: "(1) They are LIKE US, (2) They are NOT-LIKE-US, (3) They are TOO-MUCH-LIKE US ... or (4) We are NOT-LIKE-THEM" (p. 242). While each immigrant community has faced their own challenges upon arrival in the United States, and without undertaking a discussion of American immigrant history, I am going to make the assumption that Muslim immigrants have faced one of two scenarios - "They are NOT-LIKE-US" and "We are NOT-LIKE-THEM." Smith (1978) notes that the latter is often employed in rhetoric that seeks to mark a group as being "unique," but the immigration of Muslims from a host of different countries is not a new phenomenon. What has changed, however, is the debate about the values possessed by the current Syrian Muslim immigrants, and if those values are shared by Americans. In other words, while many people of Syrian descent have called America home in our history, there is a belief now that these Syrian refugees are unique and are incompatible with American values.

https://doi.org/10.24035/ijit.10.2016.005 
What happens when a nation and its people, represented by the concept of nationhood, articulate their identity through a version of Smith's (1978) typology? Anderson's (1983) work supports such a research query. First, he suggests that a nation is "an imagined political community" (p. 6). He chooses the phrase "imagined" because most people in a nation will never meet their fellow countrymen, "yet in the minds of each lives the image of their communion" (p. 6). This is a key point: Anderson is articulating an idea of nationhood that only exists in the mind due to the amnesia of historical origins, which means that the nation is a discursive concept, and its story is told, not by borders or wars, but by the way it is imagined and reimagined in the minds of its citizens. Accordingly, "After experiencing the physiological and emotional changes produced by puberty, it is impossible to 'remember' the consciousness of childhood ... Out of this estrangement comes a conception of personhood, identity ... which, because it cannot be 'remembered,' must be narrated" (Anderson 1983: 204). By comparing the birth of a nation and its adolescence to that of an individual going through puberty, Anderson (1983) articulates a powerful analogy on the lack of memory that should doom humans, as well as nations, but is overcome by invented stories and traditions.

None of this seems altogether problematic, but Anderson (1983: 7) points to the central concern with nationalism: "The nation is always conceived as a deep, horizontal comradeship, Ultimately, it is this fraternity that makes it possible, over the past two centuries, for so many millions of people, not so much to kill, as willingly to die for such limited imaginings." From the perspective of the American Muslim community, this question evokes a troubling set of soulsearching as to why an American nation, for which many Muslims have pledged loyalty, would now seek to re-write and re-imagine American history as one devoid of an Islamic influence, or to wage a war - in the emotional and psychological sense - against Islam.

And yet, Said (1978) would argue that none of this is surprising since the lack of support for Islam and the religious practices of Muslims, American or otherwise, is perfectly in line with the orientalist histories and traditions of the West and their colonial powers. Orientalism, as defined by Said (1978), "is fundamentally a political doctrine willed over the Orient because the Orient was weaker than the West, which elided the Orient's difference with its weakness" (p. 204). According to Said, Islam has always had a bad reputation in Europe, primarily due to Christian beliefs about its questionable prophecy; accordingly, "Since Mohammed was viewed as the disseminator of a false revelation, he became as well the epitome of lechery, debauchery, sodomy, and a whole battery of assorted treacheries" (1978: 62). For much of Europe, before and after the Crusades, Mohammed, and Islam, became a dual point of contention, and were oft-maligned. How shocking is it really that Islamophobia is a problem in a country like the United States, and one steeped in Christian theology, built and founded on the backs of Orientalism?

Among the many contributions of Michel Foucault to political theory is his notion of "pastoral power," which he contrives of as a government-held power based on Christian ethics. While he acknowledges the role of Christianity in bringing forth its own ethical standard, he remarks that what people are less aware of is how these ethical "standards" have spread throughout the world. While his focus seems to be on the Christian history of Europe, I argue that the United States, itself a byproduct of Christian expansionism, has adapted pastoral power in an American context, which has in turn, imbued American political institutions and sovereign decisionmaking.

Foucualt (1982) identifies four facets of pastoral power: it is predicated on the goal of attaining salvation after death; it is focused on doing good for the "flock" versus saving a sovereign's "throne"; its focus is the individual and not just doing good for the whole community; and its success relies on knowing an individual's conscience or secrets (p. 214). Taken together, Foucault's

https://doi.org/10.24035/ijit.10.2016.005 
(1982) understanding of pastoral power is one of Christian, even Catholic, sovereign power where the goal is doing what is in the best interests of individual community members, provided there is an acknowledgment that they [people] share personal information with authorities. Sullivan (2014), however, cautions against comparing American political figures and institutions to those in Europe in terms of pastoral power. They have pastoral power, but convened in a different way since American congressmen are not ministers in the religious sense, but often engage in the same welfare state-style of political and economic resource distribution. Accordingly, "The logic of pastoral power is structured into American consciousness in a parallel way, as Alexis de Tocqueville famously observed, through the dominance in the United States of Christian forms of self-knowing and monitoring" (p. 21).

What I am suggesting is that American political culture has been so rooted in a Christian political theology that even implying a separation of Christian culture and values from the political process is now often met with opprobrium. Pastoral power has become linked with notions of political theology, which has created a situation where Christianity is identified as the dominant frame with which to govern, and Islam is recognized as anti-Christian, therefore anti-government, anti-society, anti-liberalism, etc. If this seems like a stretch, then consider the work of Göle (1996) on the Tanzimat Period in Turkey (1839 to 1876). She argues that as early as the $19^{\text {th }}$ century, Westernization started to slowly erode the rigid boundaries and spaces previously established by centuries of Islamic (see Ottoman) rule. This created a situation, which stands to this day, where "the East has reviewed its own identity in light of Western standards and goals. The more it recognizes the superiority of the West, the more it loses confidence in its own specific identity and history" (Göle 1996: 51). Therefore, any articulation of religious identity, Islamic or otherwise, not seen as compatible with Western norms, is rejected and its adherents are cast out. In her critique Göle (1996) focuses on the larger picture, which is that the Western pastoral power has, at its core, a presupposition that the private sphere is often subsumed by the public sphere; and yet, Islamic culture often has a very different perspective on this issue. Private issues for Muslim families like internal affairs, daily struggles, and health become public through the act of confession. However, "The culture of Islam on the other hand, is established not only on the invisibility of the mahram sphere and of women but also on the 'secrecy' and 'nonverbalization' of the affairs taking place in the mahram realm; it is a society of silence, thus, it is antiliberal by its very organization" (Göle 1996: 52).

\section{Biopower and the "Sacred (Muslim) Man"}

The impetus for biopower comes from the mores related to power and sex, but Foucault (1978) explicitly rejects the understanding of power in the institutional sense that implies a set of citizens doing what the state has defined; rather, power "is the name that one attributes to a complex strategical situation in a particular society" that facilitates the objectification of sex (p. 93). This Foucauldian notion of "power" is then responsible for placing sex - characterized by its denial and exclusion - in a binary: "licit and illicit, permitted and forbidden ... power's hold on sex is maintained through language or rather through the act of discourse that creates, from the very fact that it is articulated, a rule of law" (p. 83).

Foucault's idea of biopower is predicated on theories of sexuality, and its regulation, as well as the role of the sovereign in maintaining the population it attempts to govern. At the heart of this work is a critique of the bourgeoisie, who deny their own sexuality, but also manage to convince the proletariat to reject their sexuality. This was based on a Victorian ethic of sexuality as something meant to be hidden, rather than enjoyed. Writes Foucault (1978), "One understands why it [the bourgeoisie] took such a long time and was so unwilling to acknowledge that other classes had a

https://doi.org/10.24035/ijit.10.2016.005 
body and a sex ... precisely those classes that it was exploiting" (p. 126). By selectively deploying sexuality when necessary, the bourgeoisie effectively created the context for the concept of a "public health" and one that is regulated by the state.

The sovereign plays an important role in setting the stage for the discussion of biopower because it has the unique power to decide who lives and who dies, especially if it feels threatened what Foucault (1978) described as the "right of rejoinder" (p. 135). However, he pulls apart this idea, arguing that "the right to life and death is a dissymmetrical one [as] the sovereign exercised his right of life only by exercising his right to kill" (p. 136) and that "one might say that the ancient right to take life or let live was replaced by a power to foster life or disallow it to the point of death" (p. 139). Once the sovereign was identified as the holder of a political and economic power, it became interested in monitoring the population's births, deaths, health, and movement. "Hence there was an explosion of numerous and diverse techniques for achieving the subjugation of bodies and the control of populations, marking the beginning of an era of "biopower'" (Foucault 1978: 140).

Muslim Americans are now being thought of as "sacred" or outcasts; such an understanding allows for their potential exclusion from civic and political life, as well as a rise in attacks against them because they are viewed as outside or beyond the law. Foucault (1978) believed biopolitics was a necessary outcome of the politicization of life, and as Agamben (1998) has noted, "the entry of zoē into the sphere of the polis ... constitutes the decisive event of modernity" (p. 4). Biopower, as the arm of sovereign power, has been identified by theorists to be the source of a number of political phenomena. In his work on AIDS, Petro (2015) adopts a Foucauldian perspective, claiming that since the sovereign determines the limits of power, it also creates the norms by which people should be judged within those limits of power. In terms of sexuality, therefore, the sovereign can determine the sexual values and standards by which people can be included or excluded in a society, which leads to a form of "moral citizenship. By President Reagan not speaking publicly about AIDS till 1986, he denied citizenship to those with the disease (Petro 2015: 7).

Another manifestation of biopower is in the work of Rana (2013) and post-9/11 racialization of Pakistani Muslims, or what he termed the "necropolitics of migration" (p. 338). As the government sought to determine who should stay in the United States and who should be forcibly removed, Pakistani Muslims, questioned for their religious and ethnic loyalties, came under intense scrutiny leading to a wave of deportations, as well as voluntary returns to Pakistan. For Rana (2013), these deportations were an exercise in sovereignty and biopolitics as the sovereign in this case the American state - determined who was expendable, especially in an economic/labor sense based on "the exclusion of the Muslim body as a racial object from the U.S. body politic" (327).

Agamben (1998) continues where Foucault (1990) left off; "he [Foucault] summarizes the process by which, at the threshold of the modern era, natural life begins to be included in the mechanisms and calculations of state power, and politics turns into biopolitics" (1998, p. 3). In other words, "the production of a biopolitical body is the original activity of sovereign power" (p. 6). But the main figure of Agamben's work is homo sacer or "the sacred man," who represents the citizen who has broken the law or an oath, and thus finds himself excluded from the body politic - a figure who can be killed, but not sacrificed. Consequently, derision, humiliation, punishment, and even death upon him by the sovereign or even other citizens is tolerated, and comes with it no punitive risk. According to Agamben (1998: 82),

Just as the law, in the sovereign exception, applies to the exception force in no longer applying and in withdrawing from it, so homo sacer belongs to God in the 
form of unsacrificeability and is included in the community in the form of being able to be killed. Life that cannot be sacrificed and yet may be killed is sacred life.

Khosravi (2007) recognizes homo sacer as a "depoliticized body," who is identified as a citizen, but without political rights. In other words, "Homo sacer personifies 'the naked life,' which differs from the politicized form of life, explicitly represented in the notion of citizenship" (p. 321). In his work on border and refugee politics in Iran, Khosravi (2007) points to the status of being an "illegal" traveler - one crossing international borders without legal permission to do so - as an example of the citizen who crosses from the legal to illegal plane, resulting in them falling out of favor with the sovereign. Taken in the context of current debates on the legal and illegal movement of Syrian refugees, it is hard not to see huge parallels, as well as recognize the salience of Agamben's work. According to Khosravi, "This is the main aspect of contemporary border politics. It exposes the border transgressors to death rather than using its power to kill" (2007: 324).

Yet, at the heart of Agamben's exploration of homo sacer, is a reference not only Foucault's (1978) understanding of biopower, but also his work on "objectification" (Foucault 1982). According to Agamben, humans are caught in the web of two conflicting practices: "state power makes man as a living being into its own specific object" and "man as a living being presents himself not long as an object but as the subject of political power" (p. 11). In other words, it is the conflict that man feels as an object that not only makes him the appropriate subject of the sovereign, but it also allows the sovereign to determine the rules or limits of life for his subjects. For Agamben (1998), Foucault's process involved "the passage from the ancient to the modern world, bringing the individual to objectify his own self, constituting himself as a subject and, at the same time, binding himself to a power of external control" (p. 119). Thus, Foucault's "biopolitics" was really "the growing inclusion of man's natural life in the mechanisms and calculus of power" (Agamben 1998: 119). Biopower, as a consequence, was inescapable; "birth ... becomes ... the immediate bearer of sovereignty" (p. 128).

A key component of understanding the life of "the sacred man" is recognizing that he is a pawn in the sovereign's enterprise, and that the sovereign is able to make political decisions, especially during times of emergency. This is what is dubbed as "the exception" and much of Agamben's work is a reply to the political theology theories of Carl Schmitt (1922), who defined the sovereign as "who decides in a situation of conflict what constitutes the public interest or interest of the state, public safety and order" (p. 6). In the current American context, Islamophobia is more than just an occasional feeling of public dislike for Muslims; it is an institutionalized effort to exclude Muslims from American political life through an expansion of "the exception." From this understanding of Schmitt (1922), it would not be far-fetched to see President George W. Bush's "War on Terror," the creation of a class of prisoners devoid of constitutional rights ("enemy combatants"), the passage of the Patriot Act, and the genuine institutional restructuring against the rights of assembly, thought, and worship.

The consequences of this extension of sovereign power has had a deleterious effect on Muslims in the United States, particularly those who attempt to speak to address social injustices. One aspect of American political culture that is often left out of debates is its focus on secularism. For example, Sullivan (2014) has pointed out that "American religion is not all about finding a common spirituality ... The sorting out of good religion and bad religion, and good religious folks from bad religious folks, and people 'of faith' from people 'not of faith' is a perennial project of the U.S." (p. 11). Sullivan argues that while the First Amendment provides for an Establishment Clause and a Free Exercise Clause, "Bad religion is established religion. Good religion is free religion" (p. 11). 
Asad (2003) has addressed what he calls "religious deprivitization" as only being a concern and a threat to modernity if it does not "further the construction of civil society (as in Poland) or promotes public debate around liberal values (as in the U.S.)" (p. 182). If, on the other hand, political religion "seeks to undermine civil society (as in Egypt) or individual liberties (as in Iran) then political religion is indeed a rebellion against modernity and the universal values of Enlightenment" (p. 182). This is a continuation of Göle's (1996) argument on Westernization: religious practices that do not agree with what the West has deemed as liberal, are irrevocably illiberal, and have no place in secular modernity. For Asad (2003), this creates a double paradox for Muslims: while the public sphere is purportedly open to all, Islam is not given permission to enter, and when Muslims are allowed to enter debate, their voices are not considered important because the values they purport to represent are inconsistent with Western host societies. According to Asad (2003), "The enjoyment of free speech presupposes not merely the physical ability to speak but to be heard, a condition without which speaking to some effect is not possible. If one's speech has no effect whatever, it can hardly be said to be in the public sphere, no matter how loudly one shouts" (p. 184)

\section{A Prescription for Troubled Times}

Towards the end of Homo Sacer, Giorgio Agamben moves away from the focus on Foucault (1978), to examine the work of Hannah Arendt (1943). In particular, Agamben (1998) wondered if the Foucauldian notion of biopower could be applied to Arendt's work on refugees. In other words, since refugees are not born in the country to which they emigrate, there are not sovereign by birth. According to Agamben, 'The refugee is truly 'the man of rights,' as Arendt suggests, the first and only real appearance of rights outside the fiction of the citizen that always covers them over" (p. 131). In other words, one's status as a refugee violated the link between "birth-nation" and "mancitizen" (p. 133).

As the government of the United States looks to resettle Syrian refugees across the breadth of the country, this move has met with widespread derision and rejection by gubernatorial and local powers that view refugees as a threat. Yet based on Agamben (1998), is it possible that these Syrian refugees are outside the scope of the law by not being sovereign by birth? Is this the political prescription for the refugee crisis? Unfortunately, this seems more like an exercise in free-thought, and less of a viable policy strategy.

I have attempted in this paper to draw on a broad array of topics - sexuality, sovereign power, political theology, nationalism, and secularism - to argue for the establishment of a comprehensive political theory to explain American Islamophobia. I have argued that the antiMuslim sentiment being expressed and experienced in the United States is uniquely American, and a product of its unique history and political culture, as much as notions of American nationhood and liberal values. However, at the root of this paper is Foucault's (1982) belief in a Christian pastoral power, as conceived of by European governments, which has been exported to the United States, and forms the bulwark of the institutional construction of American policies. Pastoral power thrives in a culture of objectification. This pastoral power thrives on a culture of confession, which is antithetical to Muslim ideas of the private and public sphere.

Concurrently, the American sovereign, has used its emergency powers to extend what was once an exception to the norm i.e. powers that deem who is capable of government protection, and who is excluded from protection. Homo sacer can now be understood as the "Muslim sacred man," who is part of the polity by virtue of residence or citizenship, but who has alleged to have broken the law or an oath by the nature of his religious practices that are viewed un-American or illiberal. Crimes perpetuated against Muslims are now becoming increasingly common in the United States,

https://doi.org/10.24035/ijit.10.2016.005 
and while there is occasional admonishment from governmental figures, the culture now is one of acceptance of Muslim exclusion rather than shock.

But, is the whole idea that we need to change the debate? The question is not if religion can work in the public sphere since Islam specifically is being targeted as not compatible while other religions are. So the issue is how to change anti-Muslim sentiment. Based on this nascent theoretical framework, I argue that the key to this change will come when those who are opposed to Islam are convinced otherwise that Islam is compatible with America and that Islam does not subsume American political values or the Constitution.

\section{References}

Agamben, G. 1998. Homo Sacer: Sovereign Power and Bare Life. New Haven, CT: Stanford University Press.

Anderson, B. 1983. Imagined comunities. Reflections on the Origin and Spread of Nationalism. London: Verso Press.

Arendt, H. 1943. We refugees. Menorah Journal 31(1): 69-77.

Asad, T. 2003. Formations of the Secular: Christianity, Islam, Modernity. New Haven, CT: Stanford University Press.

Foucault, M. 1990 (1978). The History of Sexuality, Volume 1: An introduction. New York: Vintage. . 1982. The subject and power. In Michel Foucault: Beyond Structuralism and Hermeneutics. Ed. by Hubert L. Dreyfus \& Paul Rabinow. Chicago: University of Chicago Press.

Göle, N. 1996. The Forbidden Modern: Civilization and Veiling. Ann Arbor, MI: University of Michigan Press.

Khosravi, S. 2007. The 'illegal'traveller: an auto-ethnography of borders. Social Anthropology, 15(3): 321-334.

Petro, A. M. 2015. After the Wrath of God: AIDS, Sexuality, and American Religion. New York: Oxford University Press.

Rana, J. 2013. Tracing the Muslim body: Race, U.S. deportation, and Pakistani return migration. In The Sun Never Sets: South Asian Migrants in an Age of U.S. Power. Ed. by Vivek Bald, Miabi Chatterji, Sujani Reddy\& Manu Vimalassery. New York: New York University Press.

Said, E. W. 1978. Orientalism: Western Representations of the Orient. New York: Pantheon.

Smith, J. Z. 1978. Map is Not Territory: Studies in the History of Religion. Chicago: The University of Chicago Press.

Schmitt, C. 1922. Political Theology: Four Chapters on the Concept of Sovereignty. Trans. by George Schwab. Chicago: The University of Chicago Press.

Sullivan, W. F. 2014. A Ministry of Presence: Chaplaincy, Spiritual Care, and the Law. Chicago: The University of Chicago Press.

https://doi.org/10.24035/ijit.10.2016.005 